\title{
Hegemony and Power Relation of Punggawain Manipulating the Goverment Regulation towards Bajo Ethnics Fishermen at North Tiworo District of West Muna Regency
}

\author{
Akhmad Marhadi \\ \{ahmadmarhadi@uho.ac.id\} \\ Halu Oleo University Kendari, Southeast Sulawesi, Indonesia
}

\begin{abstract}
Relation between punggawa and sawi can be categorized as unbalanced relation or not justice of their income distribution. It is more determined by the function or role of punggawa. This aims of this study is to investigate hegemony and power relation of punggawa in manipulating the goverment regulation towards Bajo ethnics fishermen at North Tiworo District of West Muna Regency. The power relation means the relation of patront-client between capital owner (punggawa) and worker (sawi) or is usually called with the term "punggawa-sawi". The theories used in this research were the theory of power relation of Foucault and theory of Capital of Bordieu. The data was collected through observation, interview, and documentation. It was analyzed through descriptive qualitative method. The result of this research shows that it has occured hegemony and power relation of punggawa in manipulating the goverment regulation towards Bajo ethnics fishermen at North Tiworo District of West Muna Regency. The capability of punggawa in controlling its members (sawi) become serious issue, either to executive or legislative. This condition aroused the hegemony and power relation in the every life aspect of Bajo ethnics fishermen. To strengthen its position, punggawa protect and add their economics assets through government regulations. It gives more power of punggawa in doing hegemony to sawi through manipulating the goverment regulation, and it gives more advantages and strengthen the position of punggawa. Therefore, the relation created hegemony from punggawa to the group of sawi that give the impact on the economics loss of sawi.
\end{abstract}

Keywords - Hegemony, power relation, punggawa, sawi, regulation

\section{Introduction}

Bajo ethnics know sea as knowing theirselves. They love sea because it is one of parts of their life and can not live without the sea. One of the main reasons is belief that their ancestors come from the sea, live in the sea, and as leader of sea (mbombonga di lao). Therefore, the sea that give them profit, goodness, health, disease, and also protect them from disaster [1]. The belief of sea is belong to all Bajo ethnics and they are free to use the result of sea. It arouses the high mobility of Bajo ethnics. They often move from one place to other places, from one island to other islands using ship (leppa), so they are also called as sea gypsiesorsea nomads [2]. The daily life of Bajo ethnics in North Tiworo in their relation to social, economy, and cultural 
systems is still traditional. The formed traditional systems are mostly depend on rules or norms of social, culture and economy relations. One of the traditional systems that still kept and maintained is relation of punggawa and sawi. Social relation of pungawa-sawion Bajoethnics in North Tiworo cretaes patront-client. The first time of its relation in terms of catching fish and dividing the result of sea run well and fulfill the justify of punggawa and sawi, but in the next condition, it arouses the unbalanced relation. The punggawa gets more profit than sawi.

The term ofpunggawa can be equalized with leader or boss. The term used to describe the relation in big scope between employee and employer that has private dependence. Sawi is like the complementer of punggawa, that can be interpreted as file man or someone who has private relation to leader. Because of the private relation punggawa usually refers to their sawias children (anaq-anaq), anaq guru (student or follower) ortau (someone who works as fishermen) [3]. Relation between punggawa and sawi can be categorized as unbalanced relation or not justice of their income distribution. It is more determined by the function or role of punggawaas main character for all sawi, included to binding the sawi with giving loan of money, giving furniture, and other helps. The characteristics and attitudes of social norm relation between punggawa and sawi determine the relationship level among Bajo ethnics in North Tiworo.

Power relation is relation between one group and other groups based on the certain ideology. Power is concept which is abstract and complex and gives effect to their life. Besides, power is also defined as the ability of someone to oppose or support other people or other groups [4]. Power refers to mechanism and strategy in arranging the together life [5].

The power should be understood as strength relation form which is immanent in space of its power operation. Therefore, the power is strategy and strength relation is as its effect [6]. The strategy found in anywhere which has system, rule, arranges, and regulation. It does not come from outside, but it can determine orders, rule, and inner relation. According to Foucault that power is a dimension of relation, in which there is relation, there is power [7]. Besides power relation, this study uses capital theory of Bourdieu. According Bourdieu, capital is not related to material but also immaterial such as social, power, position, and other relations. Someone who does not has material, but he or she has strong social network, good position, and legitimate education level, and get acknowledgement from society, so infact he/she has good capital potention that can be changed by the owners. Immaterial capital which is owned by agent can get material profit through conversion process [8]. Basically, there are several previous studies which are relevant to this study. [9] investigated relation of punggawa-sawi fishermen of BugisMakassar. It included internal and external relation and found that maintenance and condition of punggawa-sawi fishermen of Bugis-Makassar occur with connectivity of global market. [10] studied about the form of work relation between punggawa and Sawi of fishermen group in Takalar Regency, South Sulawesi" and found that the created social relation is not seperated from environment which influence the fishermen group. [11] investigated work relation of fishermen in Wara Timur District of Palopo Town and found that there is work relation between punggawa and sawi. Other study is [12] about interaction of fishermen groups in increasing living standard in Sangaji District, East Halmahera Regency and found that although the fishermen groups has done maximal efforts, it can not increase their living standard because of the limitation of fund or modal. Last, [13] studied about the relation of patront-client of fishermen in Maginti, West Muna Regency and found that their relation can be viewed from key propositions, they are success proposition, supporting proposition, and value proposition Based on the explanation and previous studies above, it has not been found study of hegemony and power relation of punggawa-sawi. This study therefore investigated hegemony and power relation of punggawa in manipulating the goverment regulation towards Bajo ethnics fishermen at North Tiworo District of West Muna Regency. 


\section{Method}

This study uses qualitative method and descriptive qualitative analysis technique, an effort to understand and interpretate the meaning of event based on the researcher perspective. It was conducted atBero, Mandike, Santigi, Santiri, Tasipi, Tiga and Desa Tondasi Villages of North Tiworo District, West Muna Regency, Southeast Sulawesi. The data was collected through observation, interview, and documentation techniques. Furthermore, this research employed a qualitative method with Snowball technique according to the purpose and objective of research. It was analyzed through descriptive qualitative technique.

\section{Results and Discussion}

Social bound between punggawa and sawi does not only get economy profit, but also developed and refered to reach social and political interest. The purpose is to strengthen the existence of punggawa in Bajo ethnics life, by using social bound between punggawa and sawi for political interest. The way is hoped can arrange and use the aids from either centre or local government to Bajo ethnics fishermen. The economy dependence of sawi to punggawa become moral bound with the obligations to follow punggawa's wish in giving its political decision.

The capability of punggawa in controlling its members (sawi) become serious issue, either to executive or legislative. Punggawais as network to build communication among fishermen groups that are controlled by big punggawa. The relation of punggawa and sawi is initially ran well, but because of many factors, it created hegemony from punggawa to the group of sawi, that give the impact on the economics lossof sawi. Even do, this condition aroused the hegemony and power relation in the every life aspect of Bajo ethnics fishermen.

In the development of social and politic aspects in region, the punggawa becomes agent to keep the government regulation and even become politic network in the life of Bajo ethnic. They are not only as modal owner in controlling economy asets, but they has big role in politic aspects. To strengthen its position in society life, punggawa protect and add their economics assets through government rules or regulations, both executive and legislative. It gives more the power of punggawa in doing hegemony to sawi through manipulating the goverment regulation, and it gives more advantages and strengthen the position of punggawa.

Punggawa uses sawi as their basis to take politics spaces. Politicians use punggawa as network to reach much votes from society. It is as result of the effect of communication and interaction of both of them to keep and save each other interests. It is done through several agreements. The agreements which are determined by punggawa such as if someone is chosen aslegislative, he/she have to protect their efforts and if there is aids from government which is proposed by legislative, it must be done through them. The chosen legislative who are supported by punggawa and sawi have to fulfill their promises and give attention to the needs of punggawa and sawi. Supportings to legislative members which are given by punggawa is like giving easy access to get helps or aids from Fishing and Sea Office. Punggawa addrees proposal of fish catching tools in fishermen groups and punggawa as the leader of group. The tools are like boat, a plaited rattan fish trap, fish net, water specs, cork, weights, and others.

Manipulating regulation is done by punggawa, in which the aids or helps actuallly given to Bajoethnics fishermen, but it is controlled by punggawa, so if the sawi want to get the helps, they have to ask to punggawa and it becomes doubt fom sawi. Therefore, the sawi have to return it in the next time and have to sell their fish to punggawa cheaply. Although, sawi aware 
that it is for them, but they know that it is because of punggawa efforts. It describes that sawi in social life still maintain humanity values because their economy life is helped by the existence of punggawa. Relation between punggawa and legislative members also refers to permission letter of catching fish, as mentioned in Fishing and Sea Minister Rule number 1 in 2013 about observing fish catching boat and fish carry boat. Chapter 2 explains that fish catching boat above 30 Gross Tonnage (GT) has to arrange their permission documentation to ministry. This rule really limits the moves of fisher. By helping form punggawa, sawi who has boat more than 30 Gross Tonnage can do catching fish without permission documentation. Punggawa do negotiation and communication to monitor official of catching fish activities. Thepunggawa hope that the report of monitor official of catching fish activities can guarantee the run of catching fish which is done by sawi. As a result, punggawa should give good services to them like giving all their needs during do monitoring. Besides, punggawa give accomodation such as transport fees, pin money, et cetera. So, permission documentation is not a problem for fishermen of Bajo ethnics. The condition above shows that it has occured hegemony and power relation of punggawa in manipulating the goverment regulation towards Bajo ethnics fishermen at North Tiworo District of West Muna Regency. Punggawa also sometime decrease the salary of sawiby the reason is to change their expenditure that they have given to monitor official. This hegemony power does not arouse protests or complaints from sawi because if sawi do that, punggawa will give sanction to them like sawi who do complaints will not participated in catching fish.

\section{Conclusion}

Based on the explanation above it can be concluded that has occured hegemony and power relation of punggawa in manipulating the goverment regulation towards Bajo ethnics fishermen at North Tiworo District of West Muna Regency. The capability of punggawa in controlling its members (sawi) become main factor of this condition. Besides, punggawa protect and add sawi economics assets through government regulations. The purpose is to strengthen their position in sawi life. It gives more power of punggawa in doing hegemony to sawi. Therefore, the relation created hegemony from punggawa to the group of sawi that give the impact on the economics loss of sawi. Further, social bound between punggawa and sawi does not only get economy profit, but also developed and refered to reach social and political interest. The purpose is to strengthen the existence of punggawa in Bajo ethnics life, by using social bound between punggawa and sawi for political interest. Punggawa usually build their relation to government, either to executive or legislative. Punggawa is as network to build communication among fishermen groups that are controlled by big punggawa. This condition aroused the hegemony and power relation in the every life aspect of Bajo ethnics fishermen. In the development of social and politic aspects in region, the punggawa becomes agent to keep the government regulation and even become politic network in the life of Bajo ethnic. They are not only as modal owner in controlling economy asets, but they has big role in politic aspects. Manipulating regulation is done by punggawa, in which the aids or helps actuallly given to Bajo ethnics fishermen, but it is controlled by punggawa, so if the sawi want to get the helps, they have to ask to punggawa and it becomes doubt for sawi. 


\section{References}

[1] W. Trisnadi, Anak-anak Orang Laut: Tumbuh Dewasa dalam Budaya yang Berubah. Yogyakarta: Universitas Gadjah Mada, 2002.

[2] D. . Sopher, The Sea Nomads: a Study of Maritim Boat People of South East Asia. Singapura: The Nation Museum, Singapura, 1971.

[3] C. Pelras, Hubungan Patron-klien pada masyarakat Bugis dan Makassar di Sulawesi Selatan dalam Tol. Makassar: Ininnawa, 2009.

[4] L. Thomas and Et.al, Language, Society, and Power: An Introduction. New York: Roudledge, 2004.

[5] Suyanto, "FRAUDULENT FINANCIAL STATEMENT Evidence from Statement on Auditing Standard No. 99," vol. 11, no. 1, pp. 117-144, 2009.

[6] M. Foucault, The History of Sexuality: An Introduction. New York: Vintage Books, 1990.

[7] M. Foucault, Seks dan Kekuasaan (Terjemahan S.H. Rahayu). Jakarta: Gramedia, 2000.

[8] P. Bourdeu, Arena Produksi Kultural: Sebuah Kajian Sosiologi Budaya. Yogyakarta: Kreasi Wacana, 2010.

[9] Lampe, "Punggawa-Sawi Nelayan Bugis-Makassar dalam Analisis Relasi Internal Dan Eksternal," J. Masy. Budaya, vol. 17, no. 1, 2015.

[10] Kusnadi, Akar Kemiskinan Nelayan. Yogyakarta: LKIS Pelangi Aksara, 2003.

[11] Khadijah, "Studi Hubungan Kerja Masyarakat Nelayan Kelurahan Ponjalae, Kecamatan Wara Timur Kota Palopo," UNHAS, 2013.

[12] F. Fargomeli, "Interaksi Kelompok Nelayan Dalam Meningkatkan Taraf Hidup di Desa Tewil Kecamatan Sangaji Kabupaten Maba Halmahera Timur,” Actadiurna, vol. 3, no. 3, 2014.

[13] Sufirudin, "Hubungan Patron-Klien di Antara Masyarakat Nelayan Desa Kangkunawe Kecamatan Maginti Kabupaten Muna Barat Provinsi Sulawesi Tenggara," J. Holistik, vol. 17, 2016. 